\title{
Benthic infauna and organism-sediment relations in a shallow, tropical coastal area: influence of outwelled mangrove detritus and physical disturbance
}

\author{
D. M. Alongi, P. Christoffersen
}

Australian Institute of Marine Science, PMB No. 3, Townsville M.C., Queensland 4810, Australia

\begin{abstract}
Sediment infauna and sedimentary structures within the shallow ( $\leq 15 \mathrm{~m}$ depth) inshore of the central Great Barrier Reef lagoon were examined seasonally for 1 yr to relate benthic faunal abundance, community composition and biogenic activity to outwelling of mangrove detritus and natural physical disturbance. Standing amounts of mangrove litter exceeded $4000 \mathrm{~g}$ dry weight (DW) $\mathrm{m}^{-2}$ in a semi-enclosed area and declined to $3.5 \mathrm{~g} \mathrm{DW} \mathrm{m}^{-2}$ at the inshore-middle shelf boundary. Macroinfaunal densities (mean $=1452$; range $=308$ to 3950 ind. $\mathrm{m}^{-2}$ ) and biomass (ash-free dry weight $=0.17$ to $6.31 \mathrm{~g} \mathrm{~m}^{-2}$ ) varied greatly among sites and seasons, with densities correlating negatively with detritus standing stocks; biomass did not relate to outwelling. Total meiofaunal densities (mean $=715$; range $=295$ to 1568 ind $10 \mathrm{~cm}^{-2}$ ) varied significantly among sites and seasons, but only turbellarians correlated positively to standing amounts of mangrove litter. Classification and ordination of nematode communities separated stations mainly on the basis of detrital loading. Species diversity $\left(\mathrm{H}^{\prime}\right)$ and evenness $\left(\mathrm{J}^{\prime}\right)$ correlated negatively with detritus standing stocks and extractable tannins derived from the litter. X-radiographs of sediment cores revealed sedimentary facies characterized by low to moderate rates of sedimentation, large patches of buried litter and bioturbation mainly in the upper 5 to $6 \mathrm{~cm}$ at the muddiest sites. X-radiographs also showed that these inshore sediments are devoid of large, equilibrium species, but subjected to episodes of scouring and resuspension by large tides and climatic disturbances. The poor nutritional quality of mangrove detritus and intermittent physical disturbances appear to be the major factors preventing the establishment of equilibrium communities and perpetuating the dominance of pioneering infaunal assemblages in this shallow, tropical inshore region.
\end{abstract}

\section{INTRODUCTION}

Coastal benthic communities are fueled by a heterogenous pool of organic detritus derived from different sources (Tenore et al. 1982, Tenore 1988). In temperate areas, coastal sediments receive organic matter derived mainly from phytoplankton blooms (Graf et al. 1983, 1984), vascular plant debris exported from tidal wetlands and estuaries (Hanson et al. 1981. Hopkinson 1985), winter blooms of seaweeds (e.g. kelp, Duggins et al. 1989) and, depending upon water depth and clarity, in situ microalgal production (Tenore 1988 and references therein). Most of the vascular plant detritus advected to adjacent subtidal sediments is derived from salt marshes, the actual amount exported being dependent upon factors such as areal extent of marsh, tidal amplitude and season.

Coastal sediments in the tropics similarly receive various types and amounts of plant-derived detritus, although the actual components are different to those in higher latitudes. Plankton production in the tropics appears to be less seasonal compared to temperate waters and dominated by the nano- and pico-size fractions (see review of Furnas 1990). It is therefore likely that most of this production is recycled in the water column rather than deposited onto the coastal seabed, as supported by the low amounts of chlorophyll $a$, degraded pigments and in situ primary 
production (excluding seagrass beds and some semienclosed coastal lagoons) measured in most subtidal sediments in the tropics (see review of Alongi 1990a).

Outwelling of leaves, bark, roots and other treecomponents derived from mangroves thus appears to be the main source of plant detritus for benthic food chains in most tropical coastal areas (Boto \& Bunt 1981, Twilley 1985; but see Fleming et al. 1990). Despite their potential importance as a source of detritus, the role of mangrove forests as regions of outwelling, particularly the actual amounts of litter exported and actual linkages to coastal food webs, has been documented for only a few regions (Rodelli et al. 1984, Flores-Verdugo et al. 1987).

In the central Great Barrier Reef (hereafter GBR) lagoon, it is estimated that the extensive mangrove forests bordering the coast export a substantial amount of litter to the adjacent nearshore (Robertson et al. 1988). Previous studies within the GBR lagoon have focused on outwelling from the mangroves of Missionary Bay off northern Hinchinbrook Island, one of the largest forests in the region (Boto \& Bunt 1981, Boto \& Wellington 1988, Alongi et al. 1989, 1992, Alongi 1990b, c, 1992, Daniel \& Robertson 1990). There are also extensive mangrove forests lining the Hinchinbrook Channel which contribute an equal amount of litter to the adjacent coastal sediments (Robertson et al. 1988).

This organic loading drives an abundant and productive bacterial community in these inshore sediments (Alongi et al. 1989, Alongi 1992) and enriches bulk concentrations of particulate carbon and nitrogen (Alongi 1990b). Variations in the distribution and abundance of epibenthos of the region relate positively to variations in the quantity of exported detritus, particularly for taxa such as penaeid shrimps which may use clumps of deposited litter as refugia from predatory fish (Daniel \& Robertson 1990).

In this companion paper we describe the effects of various amounts of mangrove detritus (pieces $\geq 0.5 \mathrm{~mm}$ ) deposited onto this shallow inshore area on the distribution and abundance of macroinfauna and meiobenthos and on nematode community structure. We also assess the sedimentary facies at these same locations in order to determine the influence of this deposited litter and the effects of natural physical disturbance (tidal scouring, wind waves) on the sedimentary fabric and organism-sediment relations.

\section{MATERIAL AND METHODS}

Study area and sediment characteristics. A complete description of the study area and sediment characteristics has been provided in the earlier companion papers (Alongi et al. 1989, Alongi 1990b, c, 1992).
Briefly, 6 stations were established in the Missionary Bay-Murray River-Hinchinbrook Channel region along the north Queensland coast (Fig. 1). Stns MB1 to MB3 are a transect from the shallow subtidal of Missionary Bay off the northern end of Hinchinbrook Island out to the Brook Islands. Stns MB4 and MB5 are near the mouth of the Murray River, which is lined with fringing mangrove forests. Stn MB6 is near the mouth of the Herbert River in the middle of the extensive, deltaic forests of Hinchinbrook Channel.

Geological and hydrographic conditions in this area have been studied earlier by Wolanski et al. (1980), Belperio (1983), Torgersen \& Chivas (1985) and Wolanski et al. (1990). Sediments of the stations have been classified as either very fine to medium sands (Stns MB1, MB3, MB4) or coarse silts (Stns MB2, MB5, MB6), moderately reducing, with low to moderate water content, and low to moderate concentrations of calcium carbonate (Alongi et al. 1989, Alongi 1990b, 1992). Organic carbon and total nitrogen concentrations range from 0.2 to $3.9 \%$ and 0.01 to $0.18 \%$ by sediment dry weight (DW), respectively, and are

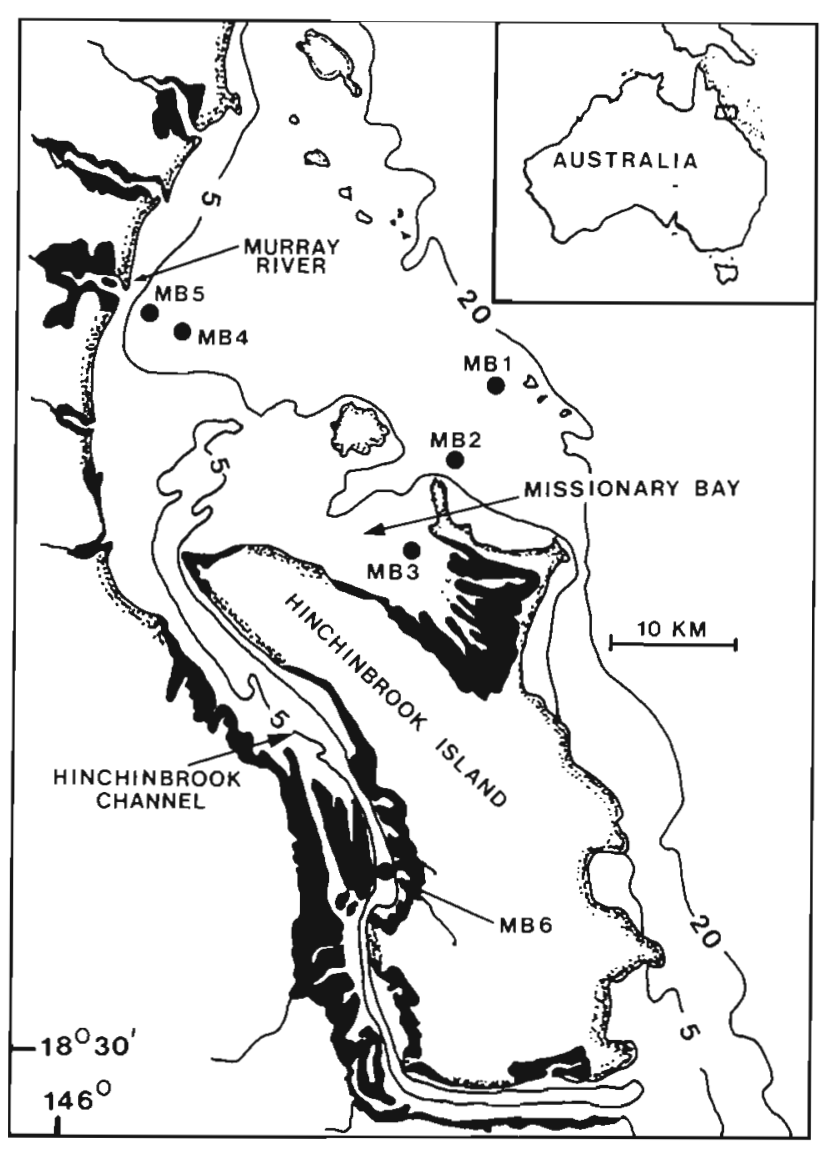

Fig. 1. Location of the 6 benthic stations in the vicinity of Hinchinbrook Island, central GBR lagoon. Darkened areas depict mangrove forests. Isobaths are in meters 
highest at stations receiving the greatest input of mangrove detritus (Alongi 1990b). Total phosphorus concentrations range from 0.013 to $0.048 \%$ by DW, but do not relate to outwelling. $C: N: P$ ratios range from 29:6:1 at Stn MB1, which receives the least amount of litter, to a high of $397: 17: 1$ at Stn MB6, which receives the most detritus.

Porewater nutrient concentrations are low (within the $\mu \mathrm{M}$ range) at all stations and not directly related to outwelling (Alongi 1990b). Interstitial ammonium (range: 10 to $310 \mu \mathrm{M}$ ) and silicate (range: 10 to $315 \mu \mathrm{M}$ ) are present in greatest concentration, with lesser amounts of phosphate (range: 1 to $12 \mu \mathrm{M}$ ) and nitrite+nitrate (range: 0.07 to $6.0 \mu \mathrm{M}$ ). Vertical profiles of both particulate and dissolved nutrients are irregular at all 6 stations. Solid-phase iron and manganese concentrations range from 8.9 to $40.0 \mathrm{mg} \mathrm{g}^{-1}$ and 107 to $496 \mu \mathrm{g} \mathrm{g}^{-1}$ sediment DW and are irregular with sediment depth, as are low concentrations of porewater Fe and Mn solutes (Alongi et al. 1992).

Bacterial cell counts are high, ranging in surface sediments (top $1 \mathrm{~cm}$ ) from 0.5 to $20.8 \times 10^{10}$ cells g $^{-1}$ DW; bacterial productivity and daily specific growth rates range from 0.02 to $5.7 \mathrm{~g} \mathrm{C} \mathrm{m}^{-2} \mathrm{~d}^{-1}$ and from 0.004 to $1.3 \mathrm{~d}^{-1}$, respectively (Alongi et al. 1989, Alongi 1992). Enhancement of bacterial activity and benthic respiration is apparent only at Stn MB6, the site of highest litter deposition. Benthic protozoan densities are low, with ciliate and flagellate numbers ranging from 23 to 511 cells $\mathrm{cm}^{-3}$ and 40 to 806 cells $\mathrm{cm}^{-3}$, respectively (Alongi 1990c). Their densities do not relate to the amounts of deposited litter (see Table 1 for summary of station positions, sedimentary and microbial characteristics).
Field sampling and laboratory procedures. Replicate $0.027 \mathrm{~m}^{2}$ modified Bouma boxcores were taken for detritus, infauna and $\mathrm{X}$-radiographic samples at each station. Cores for $X$-radiographs were taken in January-February 1988. Samples for mangrove litter and macroinfauna were taken in February, May and August 1987 and January-February 1988. Meiofauna cores were taken on these dates and in October 1987.

Samples for chitinous meiofauna were taken with 3 plastic subcores $\left(6.6 \mathrm{~cm}^{2}\right.$ surface area $)$ inserted to a depth of $10 \mathrm{~cm}$ from 1 or 2 undisturbed boxcores per site. Sampling during the first 2 cruises indicated a sample precision of $\pm 40 \%$ (1 standard error) of total mean faunal densities using 3 cores. To increase precision to $\pm 20 \%$ of the mean would have required more than 30 samples per site. As this is impractical, a sample precision of $\pm 40 \%$ was considered adequate on subsequent cruises in order to determine station and seasonal differences, and to minimize extensive sorting and identification. Each sample was preserved in a $5 \%$ formalin-seawater mixture containing Rose Bengal $\left(0.5 \mathrm{~g} \mathrm{l}^{-1}\right)$. In the laboratory, sediments were washed through a nest of 2 sieves, the larger with a mesh opening of $500 \mu \mathrm{m}$ and the smaller with a mesh opening of $45 \mu \mathrm{m}$. Animals that passed through the larger sieve and were retained on the smaller mesh were considered meiofauna. Animals were sorted and major taxa enumerated. Nematodes from the August 1987 (winter) and January-February 1988 (summer) samples were identified to species level when possible, and classified for feeding type (selective/non-selective deposit-feeder, epigrowth feeder or omnivore/predator) using the scheme of Wieser (1953). Nonchitinous meiofauna were estimated from the same

Table 1. Station positions, water depths and mean sedimentologic and microbial characteristics (summarized from Alongi et al. 1989, Alongi 1990b, c). DW: dry weight; POC: particulate organic carbon; TN: total nitrogen

\begin{tabular}{|c|c|c|c|c|c|c|}
\hline \multirow[t]{2}{*}{ Variable } & \multicolumn{6}{|c|}{ Station } \\
\hline & MB1 & MB2 & MB3 & MB4 & MB5 & MB6 \\
\hline Latitude (S) & $18^{\circ} 08^{\prime}$ & $18^{\circ} 10^{\prime}$ & $18^{\circ} 14^{\prime}$ & $18^{\circ} 07^{\prime}$ & $18^{\circ} 07^{\prime}$ & $18^{\circ} 24^{\prime}$ \\
\hline Longitude (E) & $146^{\circ} 15^{\prime}$ & $146^{\circ} 14^{\prime}$ & $146^{\circ} 12^{\prime}$ & $146^{\circ} 04^{\prime}$ & $146^{\circ} 03^{\prime}$ & $146^{\circ} 12^{\prime}$ \\
\hline Depth $(\mathrm{m})$ & 15 & 13 & 4 & 8 & 8 & 6 \\
\hline $\mathrm{Eh}(\mathrm{mV})$ & +228 & +86 & +7 & +76 & +42 & +31 \\
\hline Grain size (mm) & 0.30 & 0.06 & 0.16 & 0.11 & 0.06 & 0.04 \\
\hline Sorting $\left(\sigma_{1}\right)$ & 1.97 & 1.76 & 2.79 & 1.90 & 2.72 & 2.77 \\
\hline$\%$ Sand-gravel & 74.2 & 21.5 & 53.8 & 50.9 & 32.0 & 52.6 \\
\hline$\%$ Silt-clay & 25.8 & 78.5 & 46.2 & 49.1 & 68.0 & 47.4 \\
\hline Tannins (\% DW) & 0.002 & 0.008 & 0.014 & 0.009 & 0.013 & 0.033 \\
\hline POC (\% DW) & 0.22 & 0.70 & 1.32 & 0.82 & 1.41 & 2.60 \\
\hline TN $(\%$ DW $)$ & 0.04 & 0.08 & 0.08 & 0.09 & 0.12 & 0.12 \\
\hline$C: N: P$ & $29: 6: 1$ & $43: 6: 1$ & $138: 7: 1$ & $63: 5: 1$ & $100: 6: 1$ & $397: 17: 1$ \\
\hline Chlorophyll a $\left(\mu \mathrm{g} \mathrm{g}^{-1} \mathrm{DW}\right)$ & 0.7 & 1.1 & 1.4 & 1.2 & 1.9 & 1.0 \\
\hline Phaeopigments $\left(\mu \mathrm{g} \mathrm{g}^{-1} \mathrm{DW}\right)$ & 3.7 & 3.9 & 3.3 & 3.1 & 8.4 & 7.8 \\
\hline Bacteria (cells $\times 10^{10} \mathrm{~g}^{-1} \mathrm{DW}$ ) & 3.0 & 5.4 & 4.7 & 6.9 & 10.7 & 6.2 \\
\hline Ciliates (cells $\mathrm{cm}^{-3}$ ) & 270 & 60 & 221 & 70 & 102 & 221 \\
\hline Flagellates (cells $\mathrm{cm}^{-3}$ ) & 83 & 239 & 115 & 180 & 289 & 207 \\
\hline
\end{tabular}


cores taken for protozoa and subjected to the Percollsorbitol extraction procedure (Alongi 1990c), which is very efficient for harvesting small invertebrates (Schwinghamer 1981).

Three boxcores per station were used to estimate macroinfaunal numbers and biomass, and detritus standing stocks. Each boxcore was sieved $(0.5 \mathrm{~mm})$ and preserved in $10 \%$ buffered formalin with Rose Bengal. The animals were sorted to major taxa, enumerated and patted dry, and their preserved wet weight determined; they were then dried $\left(80^{\circ} \mathrm{C}\right.$ for 16 to $18 \mathrm{~h})$ and ashed $\left(450^{\circ} \mathrm{C}\right.$ for $\left.6 \mathrm{~h}\right)$ to estimate ash-free dry weight (AFDW). Shell-bearing organisms were decalcified in dilute $(5 \%)$ phosphoric acid prior to biomass analysis. The litter was captured by continued decantation onto a $0.5 \mathrm{~mm}$ sieve until the sediment was visibly clear. The material was then dried $\left(80^{\circ} \mathrm{C}\right.$ for $24 \mathrm{~h}$ ) and weighed. A small sample of the litter was retained during sieving and frozen for later $\mathrm{C}$ and $\mathrm{N}$ analysis.

Sediment radiographs were made from cores taken by inserting (as gently as possible) at least 2 Plexiglas liners ( $30 \mathrm{~cm}$ long, $2.5 \mathrm{~cm}$ thick, $19 \mathrm{~cm}$ wide) into 1 or 2 undisturbed boxcores at each station. The cores were then processed for $x$-rays and dissected using the procedures outlined in Alongi (1989). Primary and biogenic structures were examined using criteria outlined by Collinson \& Thompson (1989).

Data analysis. Variations in faunal numbers and biomass and in standing stocks of mangrove detritus among stations and seasons were examined using standard 2-way analysis of variance (Sokal \& Rohlf 1981). Each ANOVA was followed by a StudentNewman-Keuls (SNK) multiple comparisons test if a significant $(p<0.05)$ temporal or spatial effect was found (2-tailed test). All data was $\log (x+1)$ transformed before analysis because prior $F_{\max }$ tests indicated heteroscedasticity. Simple correlations (r) between faunal densities and the other variables (litter, sediment carbon, etc.) were determined using Pearson's product-moment coefficient. In some instances (e.g. correlations with species diversity, $\mathrm{H}^{\prime}$ ) where a third highly intercorrelated variable was found, partial product-moment correlations were calculated where the relationship between the $x$ and $y$ variable was examined with the third variable, $z$, held constant (Legendre \& Legendre 1983).

Species diversity $\left(\mathrm{H}^{\prime}\right)$ of nematodes was measured by the Shannon-Wiener information function using $\log _{2}$ (Pielou 1975), evenness (J') was calculated after Pielou (1975) and species richness (SR) was estimated using Margalef's (1958) formula. Classification of sites and nematode assemblages was done using the BrayCurtis similarity measure (Bray \& Curtis 1957) with flexible sorting and the cluster intensity coefficient $(\beta)$ set at -0.25 (Clifford \& Stephenson 1975). Nodal analysis, a cross relation between normal (stations) and inverse (species) classifications (Lambert \& Williams 1962), was performed to describe the stations on the basis of their dominant species and the species on their patterns of occurrence among stations. Comparisons of coincidence are expressed in terms of constancy, the degree to which a species is consistently found in a habitat, and fidelity, the degree to which a species selects or is relegated to a habitat. The equations for both terms are given in Tietjen (1984).

Detrended correspondence analysis (DCA) was performed to ordinate the stations using all nematode species identified. The technique is described by Hill \& Gauch (1980). The classification and ordination analyses were run combining the data sets for both seasons because of the small sample number $(3$ cores per station per season) and because of the primary interest in exploring station differences.

\section{RESULTS}

\section{Standing amounts of macroparticulate detritus}

There were significant among-station, but no seasonal, differences in the sediment concentrations of detritus (Tables 2C \& 3). Stn MB6 had the highest amounts of detritus, ranging from 3144 to $4980 \mathrm{~g}$ DW $\mathrm{m}^{-2}$, and Stn MB3 had the next highest concentration of litter at 1064 to $2688 \mathrm{~g} \mathrm{DW} \mathrm{m}^{-2}$ (Table 2C). Quantities were not significantly different between Stns MB4 and MB5 and between Stns MB1 and MB2, but Stn MB1 contained the least amount of detritus (range: 3.5 to $18.4 \mathrm{~g} \mathrm{DW} \mathrm{m}^{-2}$ ), more than half ( $68 \%$ ) of which consisted of fresh seagrass (Halodule spp.) blades

This compositional difference was reflected in the mean $C: N$ ratio of the bulk detritus with the lowest ratio at Stn MB1, the highest ratio at Stn MB2 and very similar ratios at the remaining stations (Table $2 \mathrm{C}$ ). The ratios did not change significantly $(p>0.05)$ with season.

Litter concentrations across stations and seasons correlated positively with some other sediment characteristics: carbon $(r=+0.84 ; \mathrm{p}<0.001)$ and clay content $\left(\mathrm{r}=+0.45_{i} \mathrm{p}<0.05\right)$.

\section{Interpretation of sedimentary structures}

The facies at Stn MB1 (Fig. 2) consisted of a generally uniform, subsurface fabric comprised of well-compacted, medium quartz sand (Table 1) and 
fragments of foraminifera, bivalve and scaphopod shell. The facies was moderately bioturbated with only a few surface amphipod and polychaete tubes and burrows. The random orientation of the shell and test fragments indicates subsurface particle mixing from physical disturbance (e.g. storms, cyclones).

The 2 muddiest stations, MB2 and MB5, had similar sedimentary facies (see X-radiograph of

Table 2. Total (A) wet weight and (B) ash-free dry weight macroinfaunal biomass $\left(\mathrm{g} \mathrm{m}^{-2}\right)$ and (C) macroparticulate ( $\left.\geq 0.5 \mathrm{~mm}\right)$ mangrove detritus $\left(\mathrm{g} \mathrm{DW} \mathrm{m}^{-2}\right.$ ) at the 6 central GBR lagoon stations. C: $N$ ratio depicts mean of all seasons. Values are mean $\pm 1 \mathrm{SD}$

\begin{tabular}{|c|c|c|c|c|c|c|}
\hline & \multicolumn{6}{|c|}{ Station } \\
\hline & MB1 & MB2 & MB3 & MB4 & MB5 & MB6 \\
\hline \multicolumn{7}{|c|}{ A. Wet weight biomass } \\
\hline Feb 1987 & $20.1 \pm 10.6$ & $2.5 \pm 2.4$ & $3.4 \pm 1.3$ & $26.5 \pm 3.0$ & $6.3 \pm 3.8$ & $3.9 \pm 2.0$ \\
\hline May 1987 & $19.2 \pm 2.5$ & $13.6 \pm 3.7$ & $6.4 \pm 3.6$ & $50.0 \pm 46.9$ & $34.3 \pm 36.6$ & $11.3 \pm 6.9$ \\
\hline Aug 1987 & $31.2 \pm 25.8$ & $13.7 \pm 16.8$ & $7.3 \pm 2.2$ & $7.8 \pm 2.9$ & $8.5 \pm 5.4$ & $4.7 \pm 2.9$ \\
\hline Jan-Feb 1988 & $12.2 \pm 3.9$ & $5.4 \pm 4.6$ & $8.7 \pm 5.7$ & $4.2 \pm 2.8$ & $9.7 \pm 9.3$ & $5.7 \pm 2.6$ \\
\hline \multicolumn{7}{|l|}{ B. AFDW biomass } \\
\hline Feb 1987 & $2.74 \pm 1.24$ & $0.17 \pm 0.12$ & $0.32 \pm 0.18$ & $2.43 \pm 0.22$ & $0.58 \pm 0.35$ & $0.40 \pm 0.31$ \\
\hline May 1987 & $1.48 \pm 0.61$ & $1.43 \pm 0.63$ & $0.52 \pm 0.26$ & $6.31 \pm 6.99$ & $5.13 \pm 6.25$ & $1.04 \pm 0.63$ \\
\hline Aug 1987 & $3.89 \pm 3.88$ & $0.25 \pm 0.14$ & $0.74 \pm 0.41$ & $0.41 \pm 0.14$ & $0.74 \pm 0.62$ & $0.44 \pm 0.26$ \\
\hline Jan-Feb 1988 & $1.22 \pm 0.43$ & $0.46 \pm 0.53$ & $0.90 \pm 0.67$ & $0.53 \pm 0.35$ & $0.90 \pm 0.85$ & $0.55 \pm 0.22$ \\
\hline \multicolumn{7}{|l|}{ C. Detritus } \\
\hline Feb 1987 & $10.9 \pm 5.1$ & $10.2 \pm 4.6$ & $1443.7 \pm 582.9$ & $75.2 \pm 35.8$ & $58.7 \pm 19.1$ & $3144.2 \pm 683.5$ \\
\hline May 1987 & $18.4 \pm 11.1$ & $9.8 \pm 2.7$ & $1064.3 \pm 600.9$ & $99.3 \pm 87.5$ & $78.2 \pm 36.9$ & $4295.7 \pm 955.6$ \\
\hline Aug 1987 & $4.2 \pm 2.3$ & $7.4 \pm 5.4$ & $2497.9 \pm 380.3$ & $64.2 \pm 37.1$ & $98.5 \pm 26.8$ & $4979.5 \pm 346.1$ \\
\hline Jan-Feb 1988 & $3.5 \pm 4.1$ & $19.4 \pm 17.7$ & $2687.6 \pm 326.8$ & $48.3 \pm 35.8$ & $114.1 \pm 30.6$ & $4592.1 \pm 432.9$ \\
\hline $\mathrm{C}: \mathrm{N}$ (molar) & 31.4 & 66.1 & 57.1 & 57.1 & 50.4 & 57.2 \\
\hline
\end{tabular}

Table 3. Summary of ANOVA results for macrodetritus standing stocks, total macroinfaunal biomass (AFDW) and total and major component densities of macrofauna and meiofauna. Where interaction effects were significant, trends in mean values of variates are discussed in the text. SNK test results are given below where main factors are the only significant sources of variance. $\mathrm{F}=$ February 1987, $\mathrm{M}=$ May 1987, $\mathrm{A}=$ August $1987, \mathrm{O}=$ October 1987, $\mathrm{J}=$ January-February $1988 . \cdot \mathrm{p}<0.05 ; \cdot \cdots \mathrm{p}<0.01 ;$ $\cdots p<0.001 ; \mathrm{ns}=$ not significant

\begin{tabular}{|c|c|c|c|}
\hline Variate & Station (St) & $\begin{array}{c}\text { Sources of variance } \\
\text { Season (Se) }\end{array}$ & $\mathrm{St} \times \mathrm{Se}$ \\
\hline Detritus & $6>3>\underline{54}>21 \cdots$ & ns & ns \\
\hline Macroinfaunal biomass (AFDW) & $41 \underline{5263^{*}}$ & ns & ns \\
\hline Total macrofaunal densities & $\ldots$ & $\cdots$ & . \\
\hline Polychaetes & $145236^{\circ}$ & ns & ns \\
\hline Tanaeids & $41 \underline{6235^{\circ}} \cdots$ & $\mathrm{ns}$ & ns \\
\hline Amphipods & $\ldots$ & $\ldots$ & $\cdot$ \\
\hline Decapods & $4>2165>3 \cdots$ & $\mathrm{MA}>\mathrm{J}>\mathrm{F}^{\cdots}$ & ns \\
\hline Total meiofaunal densities & $\cdots$ & $\cdots$ & $\cdots$ \\
\hline Nematodes & ns & . & $\cdots$ \\
\hline Copepods & $\cdots$ & $\cdots$ & $\cdots$ \\
\hline Ostracods & $\cdots$ & $\cdots$ & $\cdots$ \\
\hline Foraminiferans & $\ldots$ & ... & $\cdots$ \\
\hline Turbellarians & $6>\underline{5321}>4 \cdots$ & $\mathrm{J}>\mathrm{FOAM} \cdot \cdots$ & ns \\
\hline Polychaetes & $1326>4>5 \cdots$ & $\mathrm{JAM}>\mathrm{OF} \cdots$ & ns \\
\hline
\end{tabular}




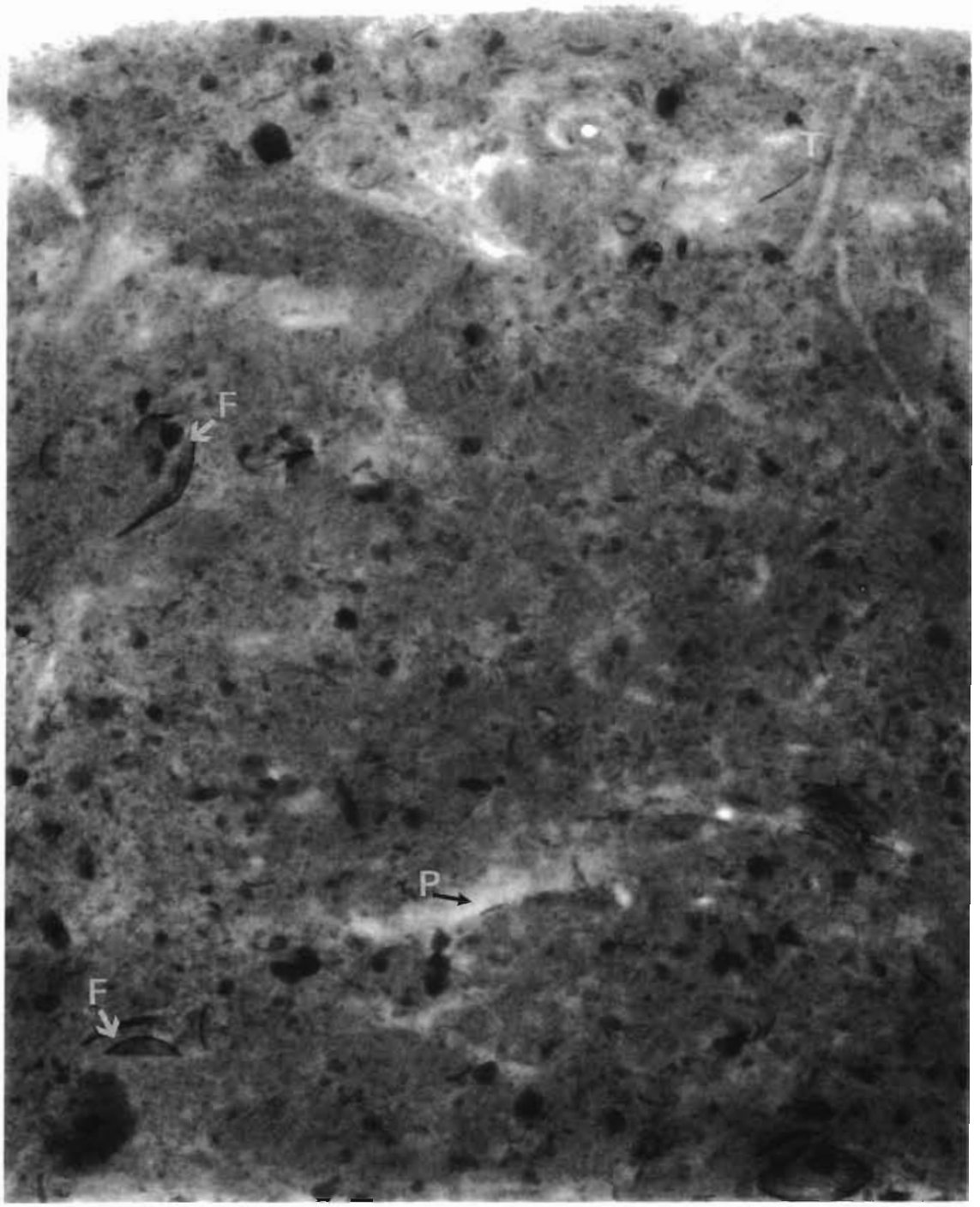

Fig. 2. X-radiograph of sediment from Stn MB1, January-February 1988 (see text for description). Length of core $=$ $24 \mathrm{~cm}$. P: Clump of seagrass detritus; $T$ : tube; $F$ : fragments of bivalve and scaphopod shell and foraminiferan tests

Stn MB5, Fig. 3) with dense clay clasts and an extensive network of tubes and small burrows in the upper 5 to $6 \mathrm{~cm}$. A few fragments of mangrove wood and gastropod and bivalve shell had been incompletely disaggregated in the lower half of the core taken from Stn MB5 (Fig. 3). A few small, subsurface tubes or burrows appeared to be relict, separated from the upper fabric by low-angle cross-bedding (erosional bands) that were in the process of being reworked.

The facies at Stns MB3 and MB4 were similar (see Fig. 4 for X-radiograph of Stn MB3), exhibiting a wellchurned, mottled fabric with irregularly oriented shells and patches of coarse sand and gravel. There was little evidence of bioturbation as most of the 'white veins' observed in the subsurface fabric were pieces of mangrove bark and twigs, as revealed by dissection. There were also a few pieces of dense mud clasts intermixed with some coarse sand + gravel fractures. A few subsurface tubes and burrows may have been recent (Fig. 4).

The sediment fabric at Stn MB6 (Fig. 5) was dominated by tiny pieces of macerated mangrove litter irregularly interspersed with pockets of fine sand. There is no clear evidence of biogenic structures or physical laminations, but the fabric is well churned. The irregular dark patches are clay clasts.

\section{Macroinfaunal patterns}

Macroinfaunal biomass varied among stations but not seasonally (Table 3 ), ranging from 2.5 to $50.0 \mathrm{~g}$ wet weight (WW) $\mathrm{m}^{-2}$ and from 0.17 to $6.31 \mathrm{~g} \mathrm{AFDW} \mathrm{m}^{-2}$, respectively (Table $2 \mathrm{~A}, \mathrm{~B}$ ). AFDW biomass was significantly greater at Stns MB4 and MB1 than at 
Fig. 3. X-radiograph of sediment from Stn MB5, January-February 1988 (see text for description). Length of core = $23 \mathrm{~cm}$. C: Clay clast; B: burrow; t: tube; P: wood; F: fragments of prosobranch gastropod and bivalve shell; white arrows in middle of radiograph denote 2 erosional contacts (EC)

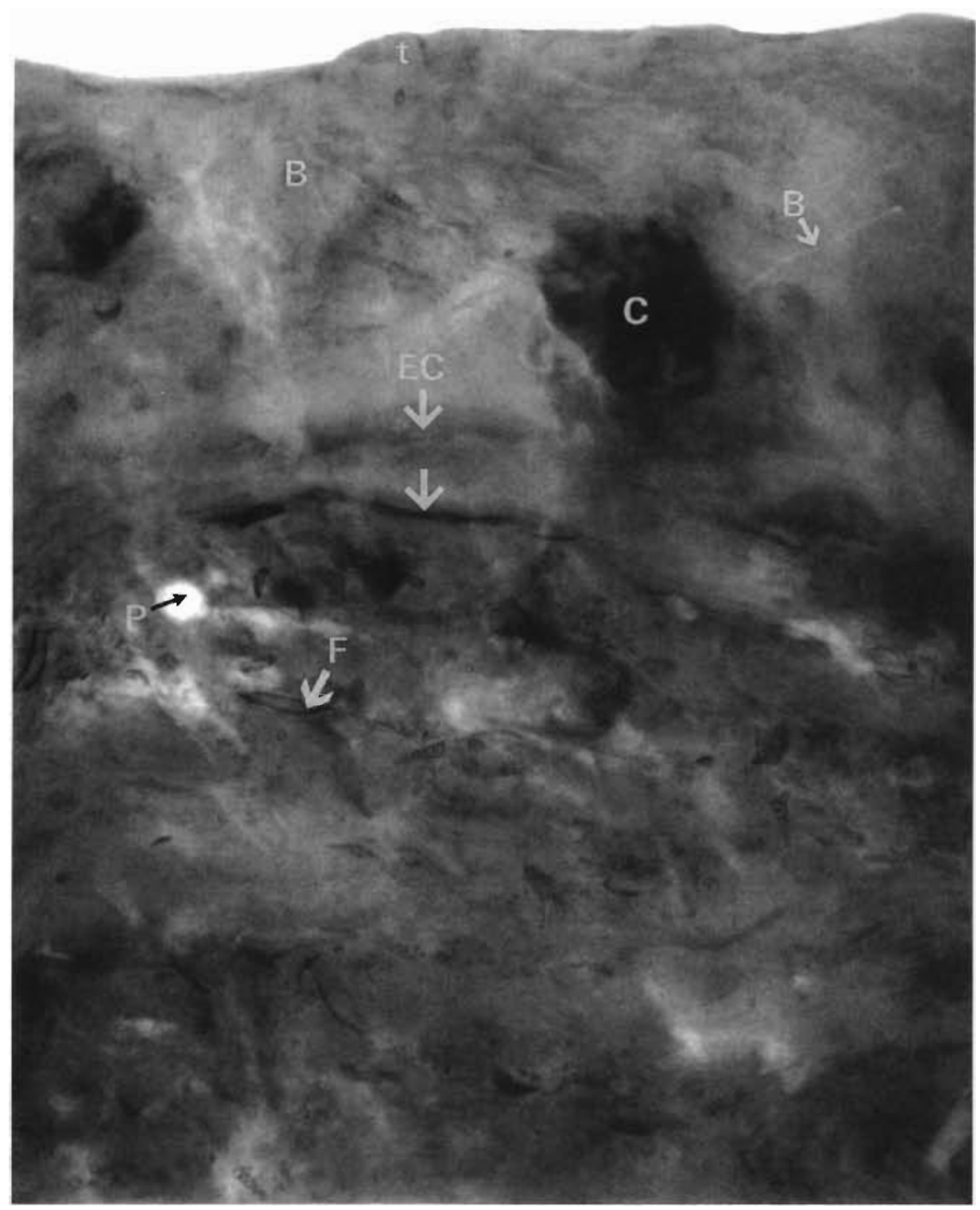

Stns MB2, MB6 and MB3 but equivalent to biomass at Stn MB5 (Table 3).

Total densities of macroinfauna ranged from 308 to 3950 ind $\mathrm{m}^{-2}$ among stations (Fig. 6) with a grand mean of $1452 \mathrm{~m}^{-2}$. Density variations among stations and seasons were significant, as were site $\times$ season interactions, indicating that differences in densities among the stations changed with season. For instance, station differences in February were (SNK test): $14>2563$; but in May were in the following order: $42 \underline{1} 5>\underline{63}$. On average (grand mean), total densities were greatest at Stns MB4 and MB1 and (summing stations) in May and August 1987 (Fig. 6).

Small, surface-dwelling polychaetes and amphipods were the dominant taxa, followed by tanaeids and decapods (mostly juvenile crabs and penaeid shrimps) and, to a much lesser extent, by bivalves, ophiuroids, cumaceans, copepods, fish, sipunculids, oligochaetes, gastropods, echinoids and asteroids
(Fig. 6). Polychaetes, tanaeids and decapods were usually most abundant at either Stn MB4 or Stn MB1 (Table 3). Amphipod abundances varied greatly with station and season, exhibiting significant interaction effects. On average, amphipods were most abundant at Stns MB4 and MB2, in May 1987 (Fig. 6). Decapods were also more abundant in the cooler months of May and August than in February 1987 and January-February 1988 (Table 3), as reflected in a significant negative correlation between decapod abundances and sediment temperature $(r=-0.49$; $\mathrm{p}<0.05)$.

Total infaunal densities related negatively to detrital standing stocks $(r=-0.41 ; p<0.05)$, percent clay $(r=$ $-0.50 ; \quad \mathrm{p}<0.01)$, carbon $(\mathrm{r}=-0.44)$ and nitrogen $(\mathrm{r}=-0.41)$ content, and positively with redox potential $(\mathrm{r}=+0.41)$. AFDW biomass correlated negatively with percent clay $(\mathrm{r}=-0.54 ; \mathrm{p}<0.01)$. Among individual taxa, polychaetes related positively to redox potential 

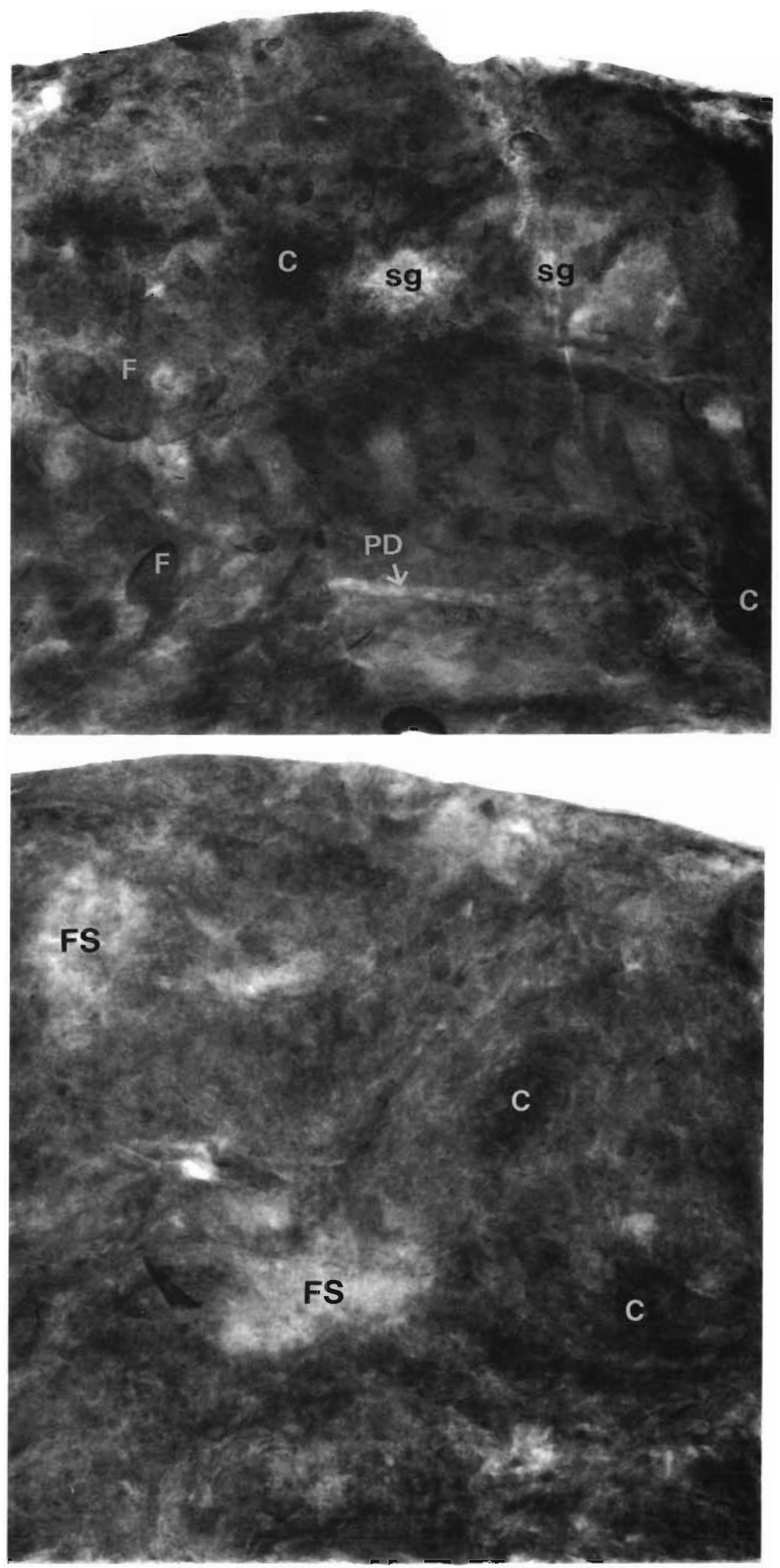

Fig. 4. X-radiograph of sediment from Stn MB3, January-February 1988 (see text for description). Length of core $=18 \mathrm{~cm}$. F: Shell fragments; PD: mangrove detritus; sg: sand-gravel; C: mud clasts
Fig. 5. X-radiograph of sediment from Stn MB6, January-February 1988 (see text for description). Length of core $=20 \mathrm{~cm}$. FS: Fine sand clumps; C: mud clasts 


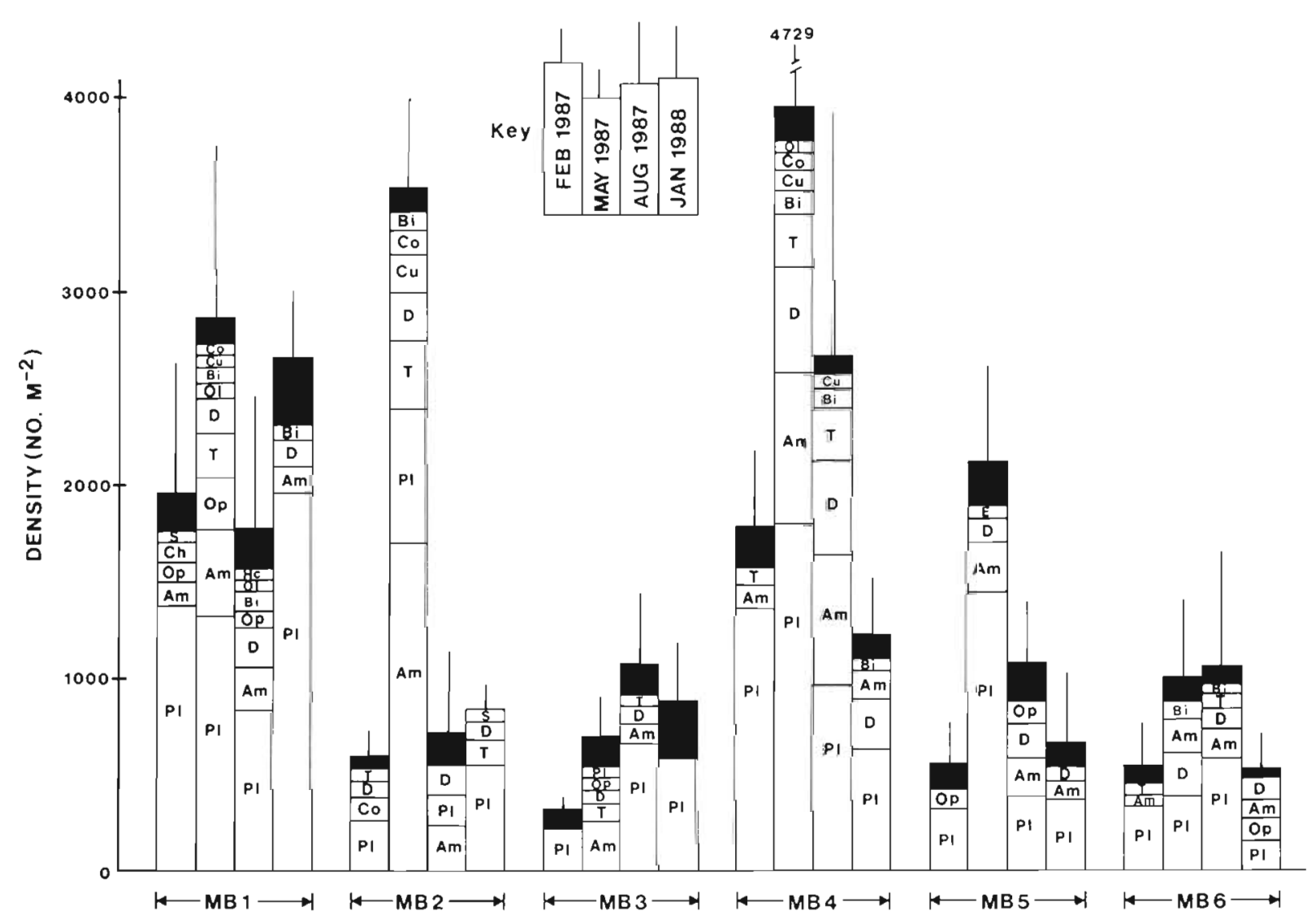

Fig. 6. Mean ( $+1 \mathrm{SD}$ ) total density (no. $\mathrm{m}^{-2}$ ) of macroinfauna and major taxa at each station for all seasons. Am: amphipods; $\mathrm{Bi}$ : bivalves; $\mathrm{Ch}$ : chordates (teleost fishes); Co: copepods; Cu: cumaceans; D: decapods; E: echinoids; Hc: hemichordates; Ol: oligochaetes; ; Op: ophiuroids; Pl: polychaetes; S: sipunculids; T tanaeids; others

$(\mathrm{r}=+0.41 ; \mathrm{p}<0.05)$ and negatively with grain size $(\mathrm{r}=$ $-0.47)$, percent clay $(r=-0.51$ ) and carbon $(r=-0.45)$ and nitrogen ( $r=-0.50)$ content. Amphipod abundances related positively with silt content $(r=+0.42)$.

\section{Meiofaunal patterns}

Total meiofaunal densities were highly variable, exhibiting seasonal and station differences and interaction effects (Table 3). Among stations, total densities ranged from 295 to 1568 ind $10 \mathrm{~cm}^{-2}$ with an overall mean of 715 ind. $10 \mathrm{~cm}^{-2}$ (Fig. 7). Individual taxa were abundant in the following order: nematodes (73\% of mean total) > harpacticoid copepods $(10 \%)>$ polychaetes $(3 \%)>$ turbellarians $(3 \%)>$ ostracods $(2 \%)>$ foraminiferans $(1 \%)$. Minor taxa $(8 \%)$ included amphipods, tanaeids, bivalves, isopods, kinorhynchs, oligochaetes, halacarids, cnidarians and larval or juvenile stages of macroinfaunal taxa (e.g. ophiuroids\}. Nematodes did not vary significantly with station but, as with copepods, ostracods, and foraminiferans, exhibited strong seasonal and inter- active effects (Table 3 ). The very highly significant interaction terms (Table 3) indicate that density differences among stations changed with each season. For instance, in February 1987 station differences in total meiofaunal densities (SNK test) were: $3>$ 46251 ; in August they were as follows: $14>6352$ (Fig. 7).

Only turbellarians and meiofaunal polychaetes did not exhibit significant interaction effects (Table 3 ). Turbellarians were most abundant at Stn MB6 and polychaetes were least abundant at Stn MB5, although both taxa were generally most abundant in January-February 1988.

Total meiofaunal numbers related positively to redox potential $(r=+0.52 ; p<0.05)$. Among taxa, turbellarians correlated positively with sediment temperature ( $\mathrm{r}=$ $+0.40)$, tannins ( $\mathrm{r}=+0.65 ; \mathrm{p}<0.001)$, carbon content $(\mathrm{r}=+0.50)$ and detrital standing stocks $(\mathrm{r}=+0.50)$. Copepods related positively to Eh $(r=+0.64 ; \mathrm{p}<0.001)$, but negatively to grain size $(r=-0.59 ; p<0.01)$, percent silt $(r=-0.43)$ and carbon $(r=-0.44)$ and nitrogen $(r=-0.56)$ content. Meiofaunal polychaetes correlated negatively with grain size $(r=-0.46 ; p<0.05)$. 


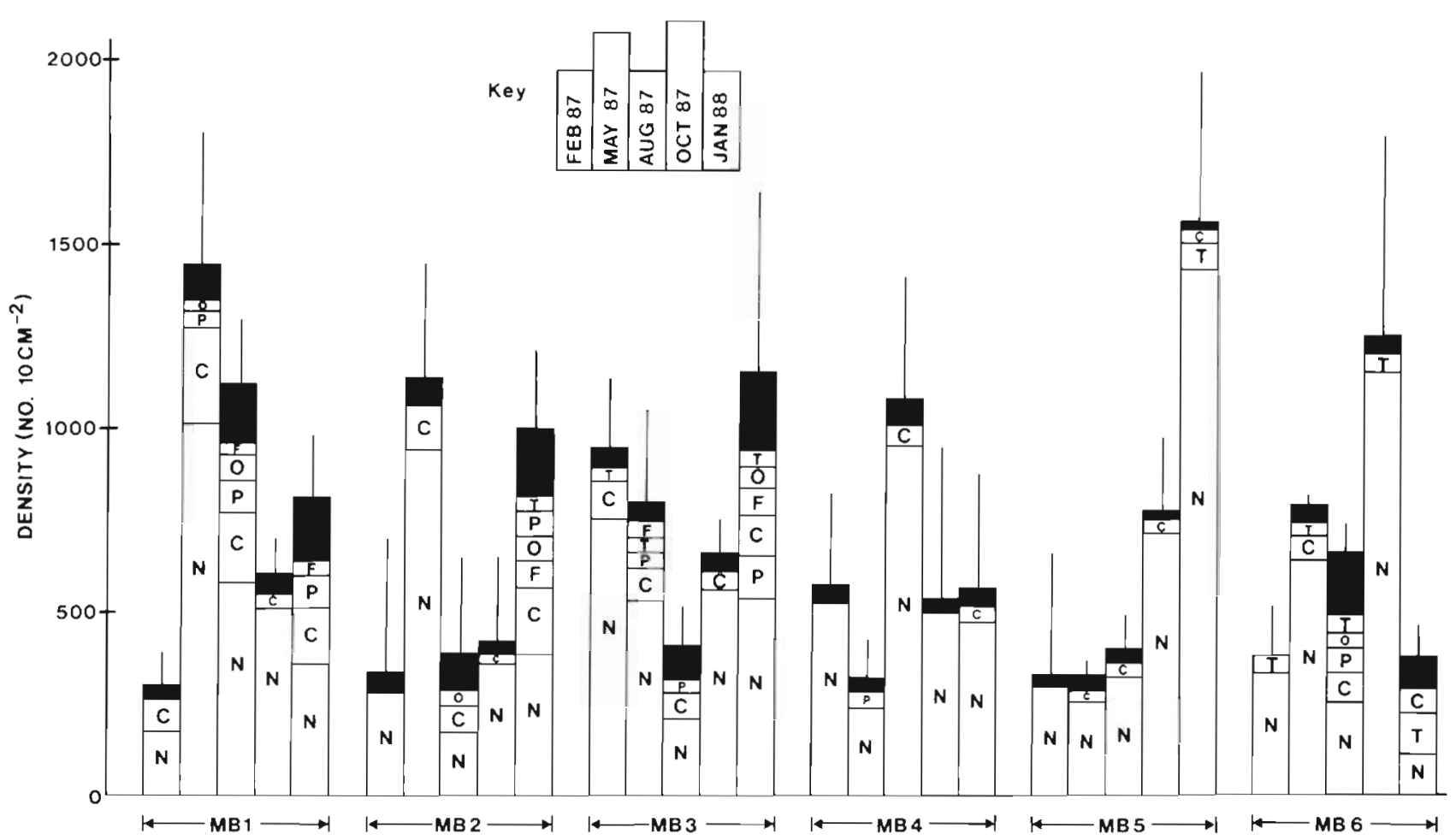

Fig. 7. Mean $(+1 \mathrm{SD})$ total density (no. $10 \mathrm{~cm}^{-2}$ ) of meiofauna and major taxa at each station for all seasons. C: Harpacticoid copepods (adults + nauplii); F: foraminiferans; N: nematodes; O: ostracods; P: polychaetes; T: turbellarians; : others

\section{Nematode community structure, diversity and trophic composition}

The normal classification of stations (both seasons and all 159 species identified) separated Stn MB6 from both stations off the Murray River (MB4 and MB5) and from the 3 transect stations off the northern end of Hinchinbrook Island which comprised a distinct cluster of the 2 sandier stations (MB1 and MB3) agglomerated with the muddier Stn MB2 (Fig. 8A). The ordination of the collections (Fig. 8B) demonstrated a clearer distinction between Stn MB6 and the other 5 sites along Axis 2. Axis 1 divided Stns MB1 and MB2 (containing the least amounts of detritus; see Tables 2 \& 3) with high scores from the other stations with greater detrital loading and lower scores. Both axes explained most of the variance with eigenvalues of 0.637 and 0.348 , respectively.

Of the 159 species identified, 46 had relative abundances $\geq 0.5 \%$ averaged over all 6 stations (Table 4). The epigrowth-feeders Dorylaimopsis punctata and Spilophorella paradoxa and the deposit-feeders Terschellingia longicaudata, Theristus sp. 9 and Theristus sp. 8 were the 5 most abundant species.

Of all the species, 27 had mean relative abundances $\geq 1.0 \%$ and were agglomerated into 2 main species groups in an inverse classification (Fig. 9), then were further analyzed using nodal analysis. The first cluster consisted of 10 species (species numbered 1, 10, 13, 3, $9,12,2,5,14$ and 16) that occurred most consistently as a group at Stns MB1, MB2 and MB3. The second agglomeration (code numbers 4 to 27 at the bottom of Fig. 9) occurred most consistently as a group from Stns MB3 to MB6.

The patterns of constancy and fidelity among these dominant species (Fig. 9) explain the fair degree of separation among stations as depicted in the classification and ordination models (Fig. 8). For instance, Stn MB6 was characterized by the strong preferences of Sabatieria spp. 4 and 5. Terschellingia longicaudata, Paramonohystera sp. 2 and Theristus sp. 9, whereas the most dissimilar site, Stn MB1, was preferred by Innocuonema sp. 1, Viscosia sp. 1. Theristus sp. 4 and Sabatieria sp. 2. Some species were not faithful to a particular station, exhibiting moderate to high constancy at all or nearly all of the 6 stations. These include Cheironchus sp. 1, Marilynia oculissoma, Ptycholaimellus sp. 1, Spilophorella paradoxa, Dorylaimopsis punctata and Elzalia sp. 1.

Species diversity ranged from 2.02 (MB6) to 3.13 (MB1). Evenness was also most divergent between these 2 stations (Table 5). Species richness was highest at Station MB1; most species (65) were identified at this site (Table 5). Species diversity $\left(\mathrm{H}^{\prime}\right)$ was a function 


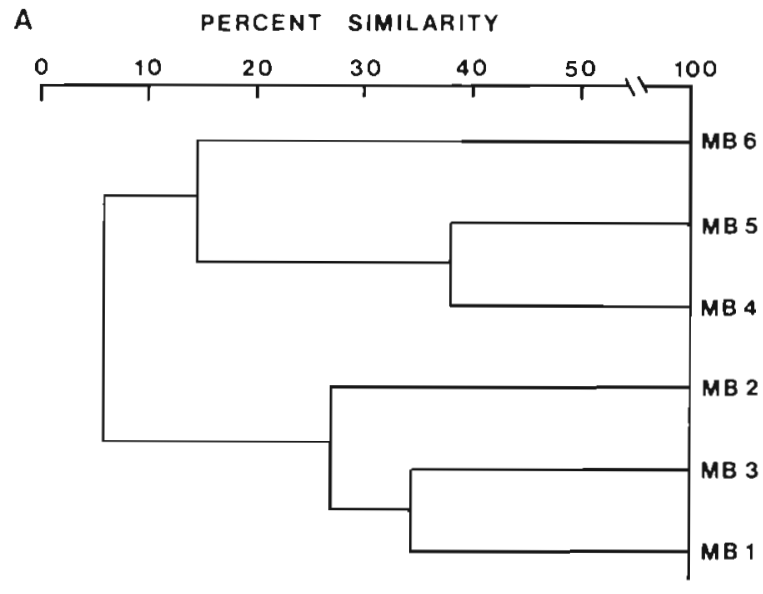

B

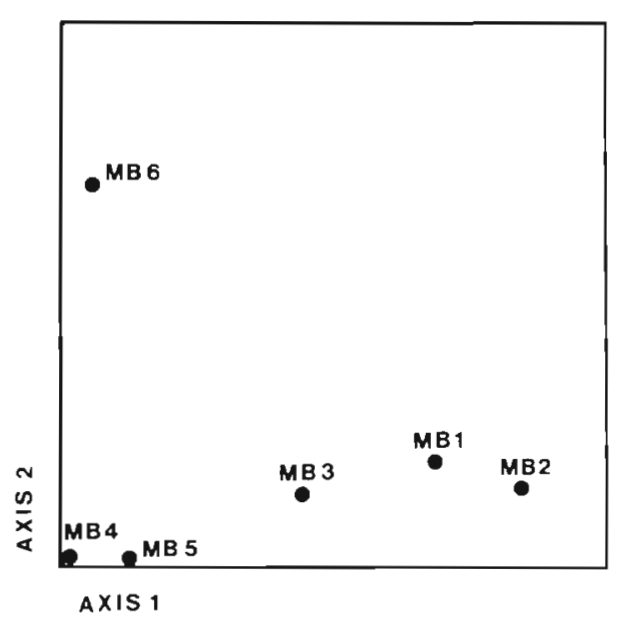

Fig. 8. (A) Normal classification of stations using all nematode species identified (August 1987, January-February 1988). (B) Detrended correspondence analysis of collections of all nematodes from all 6 stations (August 1987, JanuaryFebruary 1988)

of both evenness $(r=+0.95 ; p<0.01)$ and species richness $(r=+0.88 ; p<0.05)$. Diversity and evenness related negatively to detritus standing stocks $(r=-0.66$ and -0.75 respectively; $p<0.05$ ) holding an intercorrelation with grain size $(r=-0.78$ and $-0.79 ; p<0.05)$ constant SR also correlated with grain size $(r=+0.84)$. H' and $J^{\prime}$ also correlated with Eh $(r=+0.90$ and +0.88 respectively) as well as with extractable tannins ( $\mathrm{r}=-0.77$ and -0.86). All correlations remained significant when intercorrelations were held constant.

Non-selective deposit-feeders and epigrowth-feeders were the dominant trophic types at all 6 sites (Fig. 10), ranging from 24 to $47 \%$ and from 23 to $38 \%$ of all species identified, respectively. The relative abundance of selective deposit-feeders varied little among stations, ranging from 11 to $19 \%$ at Stns MB1 to MB5 and $24 \%$ at Stn MB6. Omnivore/predators comprised
$<10 \%$ of total relative abundance at Stns MB4 to MB6 but were relatively more abundant at Stns MB1 (23\%), MB2 (17\%) and MB3 (11\%)

On average, deposit-feeders (selective and nonselective) comprised $>50 \%$ of total relative abundances at all stations, except at Stn MB1, where epigrowth-feeders and omnivore/predators dominated (Fig. 10)

\section{DISCUSSION}

The deposition and burial of various quantities (4 to $4980 \mathrm{~g} \mathrm{DW} \mathrm{m}^{-2}$ ) of mangrove detritus in this shallow inshore area does not result in the enrichment of infaunal numbers or biomass, but rather to a diminution of species richness and diversity, as shown by the free-living nematode communities. Total macroinfaunal densities related negatively to the standing amounts of mangrove detritus, with most individual taxa relating to a variety of other edaphic characteristics. With the exception of the turbellarians, meiofaunal taxa behaved similarly, showing no relationship to the deposited litter.

The analysis of nematode community structure revealed that the response of benthic infaunal assemblages may be more qualitative than quantitative. Nematode species diversity and equitability (evenness) related inversely to detritus standing stocks and extractable tannins, even after accounting for correlations with other sedimentary characteristics, such as grain size and redox potential. Highest diversity $\left(\mathrm{H}^{\prime}\right)$ was found at Stn MB1, which was farthest from the influence of mangrove outwelling, whereas lowest species diversity occurred at Stn MB6, where mangrove litter accounts for up to between 35 and $45 \%$ of total sedimentary organic carbon (Alongi 1990b). The diversity, evenness and species richness of these inshore assemblages are less than those calculated by Tietjen (1991) for taxocenes inhabiting middle and outer shelf sands across the central GBR continental shelf, which receive little or no mangrove litter. Total densities of meiofauna and macroinfauna are also, on average, greater at these offshore sites (Alongi 1989).

The patterns of infaunal abundance observed in this inshore area of the central GBR lagoon are in contrast to most across-shelf gradients on temperate and boreal shelves where inshore (inner shelf) communities are enriched by estuarine outwelling compared to middle and outer shelf habitats that are limited by detrital availability (e.g. Hanson et al. 1981; see references in McLuskey \& McIntyre 1988).

Inshore benthic communities of low biomass occur on many other tropical shelves (see review of Alongi 1990a), but usually for different reasons, including 
Table 4. Percent relative abundance of dominant nematode species $(\geq 0.5 \%)$ found at the inner GBR lagoon stations, summer and winter samples combined. Numbers in parentheses rank the 10 most abundant species

\begin{tabular}{|c|c|c|c|c|c|c|}
\hline \multirow[t]{2}{*}{ Species } & \multicolumn{6}{|c|}{ Station } \\
\hline & MB1 & MB2 & MB3 & MB4 & MB5 & MB6 \\
\hline Innocuonema sp. 1 & 8.0 & & 1.8 & & & \\
\hline Sabatieria sp. 1 & 2.1 & 9.1 & 1.8 & & & \\
\hline Viscosia sp. 1 & 2.9 & 1.7 & & 1.6 & & \\
\hline Halalaimus sp. 1 & 2.5 & 2.8 & & & & \\
\hline Theristus sp. 1 & 1.8 & 3.0 & & & & \\
\hline Spininia parasitifera & 1.0 & 2.1 & & & & \\
\hline Spilophorella paradoxa (2) & 4.9 & & 9.2 & 10.7 & 9.8 & 1.9 \\
\hline Scaptrella sp. 1 & 2.9 & & & & 1.5 & \\
\hline Paramonohystera sp. 1 (8) & 2.1 & 11.5 & 2.6 & & & \\
\hline Pomponema sp. 1 & 4.5 & & & & & \\
\hline Sabatieria sp. 2 & 4.0 & 1.7 & & 5.9 & & \\
\hline Quadricomasp. 1 & 1.4 & & 4.0 & 1.0 & 0.8 & \\
\hline Terschellingia longicaudata (3) & 2.0 & 0.7 & 2.4 & 2.5 & 2.7 & 19.1 \\
\hline Parodontophora sp. 1 & 2.6 & 1.6 & 1.8 & & & 0.4 \\
\hline Cheironchus sp. 1 & 3.4 & 1.5 & 2.0 & 0.5 & & 2.7 \\
\hline Dorylaimopsis punctata (1) & 10.4 & 7.5 & 6.0 & 2.6 & 15.7 & 10.7 \\
\hline Theristus sp. 4 & 2.6 & 3.8 & & & & \\
\hline Marilynia oculissoma & 3.9 & 1.0 & 5.0 & 1.9 & & 2.0 \\
\hline Mononcholaimus sp. 1 & 2.4 & 2.5 & & & & \\
\hline Ptycholaimellus sp. 1 & 1.3 & 6.6 & 1.0 & 0.8 & 1.2 & \\
\hline Mononcholaimus sp. 2 & 2.0 & & 0.8 & & & \\
\hline Paracanthonchus sp. 1 & 0.9 & & & 2.8 & & \\
\hline Siphonolaimus sp. 1 & 0.5 & 1.2 & 1.2 & 0.7 & & \\
\hline Elzalia sp. 1 (6) & 1.2 & 5.0 & 1.6 & & 8.9 & 1.8 \\
\hline Hopperia sp. 1 & 1.2 & 1.8 & & & 2.3 & \\
\hline Laimella sp. 1 & 0.5 & 2.5 & & & & \\
\hline Parasphaerolaimus sp. 1 & & 3.2 & & & & \\
\hline Vasostoma sp. 1 & & 5.5 & 1.0 & & & \\
\hline Choanolaimus sp. 1 & & 3.1 & & & & \\
\hline Viscosia sp. 3 & & 3.4 & & & & \\
\hline Theristus sp. 8 (5) & & & 20.5 & & & \\
\hline Terschellingia sp. 3 & & & 4.0 & 3.8 & 2.8 & \\
\hline Dichromadora sp. 2 & & & 5.7 & 1.4 & & \\
\hline Pseudopelagonema sp. 1 & & & 6.1 & 3.5 & 2.6 & \\
\hline Theristus sp. 9 (4) & & & 3.0 & 7.4 & 10.1 & 2.5 \\
\hline Theristus sp. $10(10)$ & & & & 15.0 & & \\
\hline Halalaimus sp. 6 (9) & & & & 7.2 & 8.8 & \\
\hline Paramonohystera sp. 2 (7) & & & & 3.0 & 2.2 & 13.2 \\
\hline Sphaerolaimus sp. 2 & & & & 1.2 & 1.0 & 1.3 \\
\hline Cervonema sp. 2 & & & & 0.5 & & 2.5 \\
\hline Theristus sp. 11 & & & & 1.0 & 4.6 & \\
\hline Monhystera sp. 4 & & & & & 4.1 & \\
\hline Sabatieria sp. 4 & & & & & 4.8 & 6.2 \\
\hline Stylotheristus sp. 1 & & & & 4.8 & 1.0 & \\
\hline Metalinhomoeus sp. 2 & & & & & 1.8 & 2.3 \\
\hline Sabatieria sp. 5 & & & & & & 14.0 \\
\hline
\end{tabular}

periodic anoxia, sediment instability caused by thixotropic fluid muds, and 'estuarization' (in sensu Longhurst \& Pauly 1987). The latter phenomenon occurs when inner regions of tropical shelves are covered by poorly oxygenated, low-salinity water derived from river runoff during monsoons. Such episodes occur regularly off Iarge tropical rivers (e.g. the Amazon; Aller \& Aller 1986) and off coasts of the wet tropics (e.g. India; Seshappa 1953, Harkantra \&
Parulekar 1987). Upwelling areas are an exception, where benthic standing stocks are high beneath the highly productive surface waters (Rowe 1981).

In the central GBR lagoon, such phenomena generally do not occur, and so other factors must account for the observed patterns of low to moderate densities and low biomass of a predominantly surface- (or near-surface-) dwelling infauna. These include: (1) low food availability, (2) physical disturbances and 


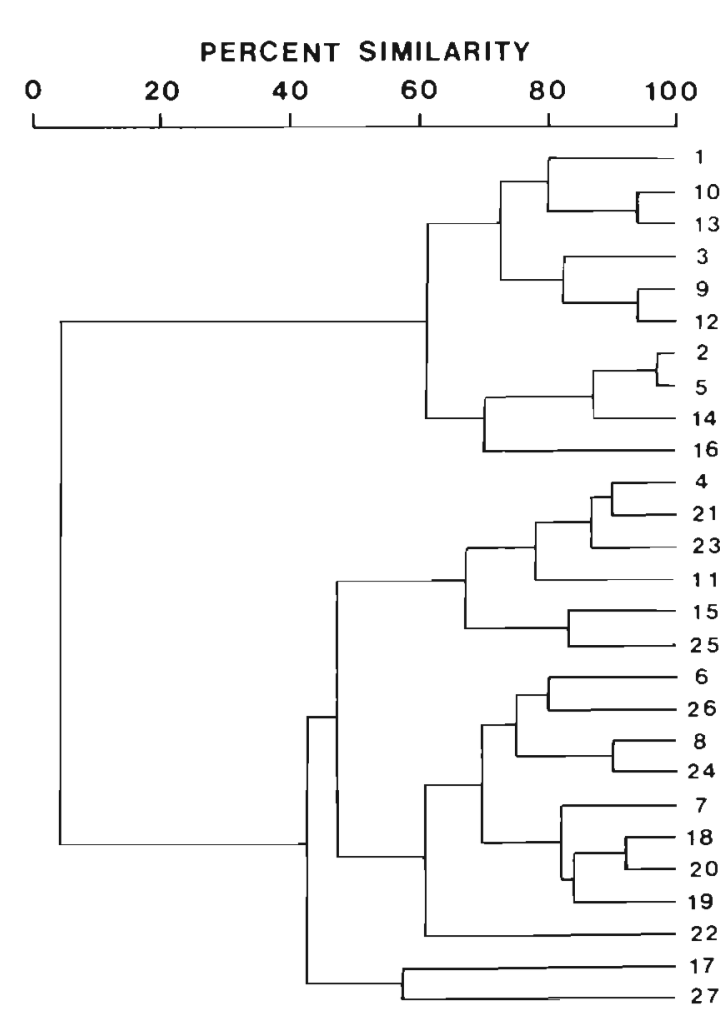

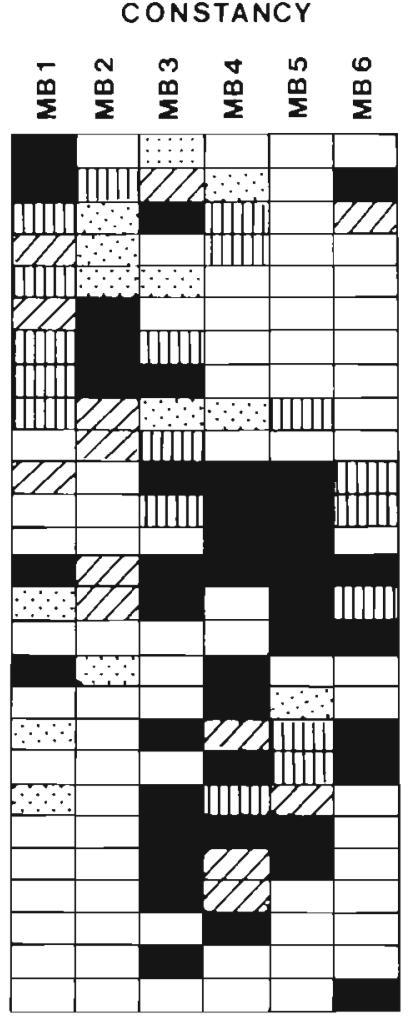

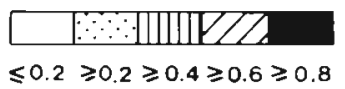

FIDELITY
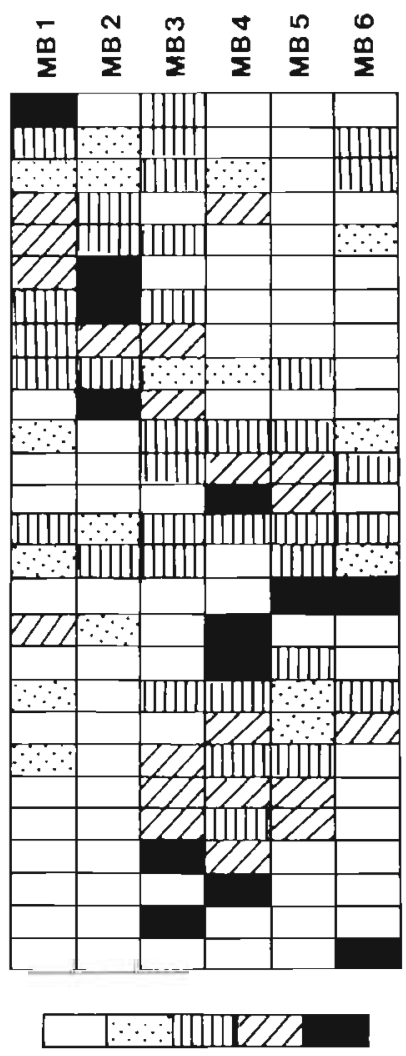

$\leqslant 0.5 \geqslant 0.5 \geqslant 1.0 \geqslant 2.0 \geqslant 3.0$

Fig. 9. Inverse classification of the dominant (mean relative abundance $\geq 1.0 \%$ ) nematode species at al. 6 stations (August 1987 , January-February 1988) and their nodal statistics showing constancy and fidelity indices. Key to species: (1) Innocuonema sp. 1; (2) Sabatieria sp. 1; (3) Viscosia sp. 1; (4) Spilophorella paradoxa; (5) Paramonohystera sp. 1; (6) Sabatieria sp. 2; (7) Quadricoma sp. 1; (8) Terschellingia longicaudata; (9) Parodontophora sp. 1; (10) Cheironchus sp. 1; (11) Dorylaimopsis punctata; (12) Theristus sp. 4; (13) Marilynia oculissoma; (14) Ptycholaimellus sp. 1; (15) Elzalia sp. 1; (16) Vasostoma sp. 1; (17) Theristus sp. 8; (18) Terschellingia sp. 3; (19) Dichromadora sp. 2; (20) Pseudopelagonema sp. 1; (21) Theristus sp. 9; (22) Theristus sp. 10; (23) Halalaimus sp. 6; (24) Paramonohystera sp. 2; (25) Sabatieria sp. 4; (26) Stylotheristus sp. 1; (27) Sabatieria sp. 5

(3) moderate to high predation pressure by epibenthos and demersal fishes.

The former 2 explanations appear to be the most likely factors because epifaunal densities and numbers of bottom-dwelling fish are low in this area (Daniel \& Robertson 1990). Seasonal variations in the amounts of mangrove detritus deposited to the seabed in this

Table 5. Species diversity $\left(\mathrm{H}^{\prime}\right)$ and evenness $\left(\mathrm{J}^{\prime}\right)$, species richness (SR) and number of species (NS) per station in the inner GBR lagoon. Values depict summed winter and summer data

\begin{tabular}{|lcrrr|}
\hline Station & $\mathrm{H}^{\prime}$ & $\mathrm{J}^{\prime}$ & SR & NS \\
\hline MB1 & 3.13 & 0.75 & 10.42 & 65 \\
MB2 & 2.42 & 0.68 & 6.03 & 35 \\
MB3 & 2.11 & 0.59 & 5.89 & 36 \\
MB4 & 2.65 & 0.66 & 8.08 & 54 \\
MB5 & 2.17 & 0.61 & 5.01 & 35 \\
MB6 & 2.02 & 0.56 & 6.81 & 36 \\
\hline
\end{tabular}

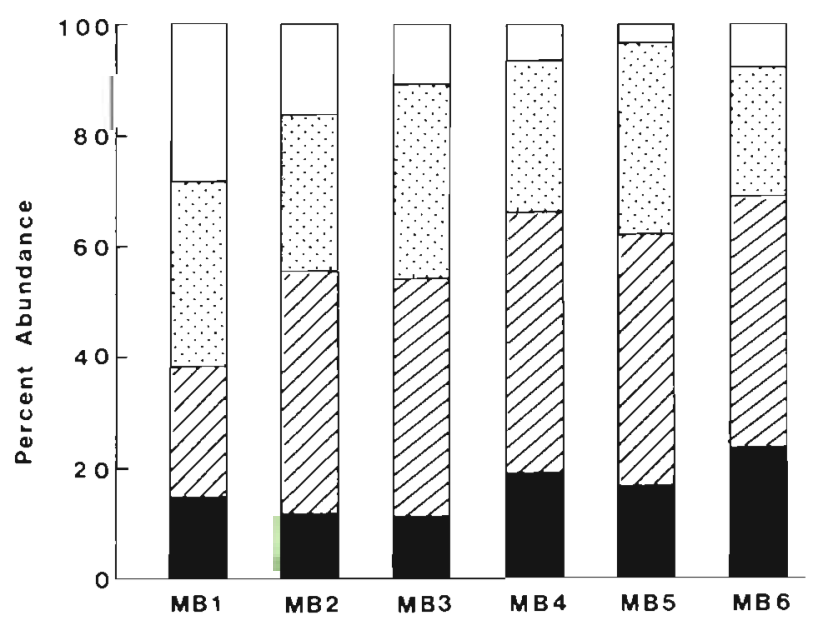

Fig. 10. Trophic structure of nematode communities (percentage of relative abundance) at all 6 stations. Selective deposit-feeders; 6 non-selective deposit-feeders; Uepigrowth feeders; Domnivore/predators 
region explain a significant proportion of the variance in total and component densities of epibenthos. Teleosts (mostly Gobiidae) and penaeid prawns respond positively to the litter ( $\geq 2 \mathrm{~mm}$ pieces) which may provide a refuge from predatory fish. However, these clumps of larger ( $\geq 2 \mathrm{~mm}$ ) pieces of litter are generally more patchy than the finer $(\sim 0.5 \mathrm{~mm})$ debris, occurring in highest concentration within the tidal mangrove creeks. Moreover, densities $\left(<2\right.$ ind. $\left.\mathrm{m}^{-2}\right)$ and biomass (0 to $740 \mathrm{mg} \mathrm{DW} \mathrm{m}^{-2}$ ) of epibenthos were lower than those recorded in other studies. Daniel \& Robertson (1990) attributed these patterns and the low abundance of epifauna to physically harsh conditions and the low food quality of mangrove litter.

It is clear that this detritus is of low nutritional quality, as reflected in its high C.N ratio (see Table 2 ) and as gleaned from other benthic studies on the decomposition kinetics of mangrove (Rhizophora spp.) detritus (Rice \& Tenore 1981, Zieman et al. 1984) and its suitability as a source of food for bacteria (Alongi et al. 1989), protozoa (Alongi 1990c), meiobenthos (Alongi 1987, Tietjen \& Alongi 1990) and macrofauna (Tenore 1983, Giddins et al. 1986). Nearly all of the laboratory growth studies found a similarly negative, or slightly positive, growth response (as $r$, intrinsic rate of natural increase) and low carrying capacity (Tenore 1983, Tietjen \& Alongi 1990). Most mangrove (mainly Rhizophora spp.) detritus is very refractory and decomposes very slowly compared to seaweeds and even compared to other vascular plants, such as marshgrasses (Rice \& Tenore 1981), which show a different mode of decomposition with respect to total nitrogen content and amino acid composition (Zieman et al. 1984).

The poor growth response of benthic organisms to mangrove detritus may be caused not only by its refractory nature, but also by polyphenolic acids (tannins) leached from the material. For example, Poovachiranon et al. (1986) found that feeding rate of the amphipod Parhyale hawaiensis was poor on a diet of tannin-rich mangrove detritus. Similarly, the depositfeeding nematode Terschellingia longicaudata did not grow on fresh, tannin-rich Rhizophora stylosa leaves, grew poorly on tannin-poor leaves of Avicennia marina, but grew best on a diet of tannin-free, mixed cereal (Alongi 1987).

Tannin content may, however, act with available nitrogen as a hierarchical feeding cue (Valiella et al. 1984, Tietjen \& Alongi 1990), whereby complex relationships may exist between detrital nitrogen content, tannin content and age. For instance, the nematode Monhystera sp. grew poorly in the laboratory on a diet of fresh Rhizophora stylosa detritus but grew very well on a mixed diet of fresh $R$. stylosa detritus and cereal (Tietjen \& Alongi 1990), suggesting either that the cereal absorbed (or adsorbed) the tannins or that the high nitrogen content of the cereal more than compensated for the high tannin content of the cereal-litter mixture, as similarly observed for the marsh gastropod Melampus bidentatus by Valiella et al. (1984).

Total sedimentary $\mathrm{N}$ content in this region relates well to the standing crop of deposited litter (Alongi $1990 \mathrm{~b}$ ), suggesting that most of the total sedimentary nitrogen is mangrove-derived and nutritionally unavailable. Total $N$ content is not always a good predictor of nutritional availability of sediments because many $\mathrm{N}$-rich, organic complexes, such as fulvic and humic acids, are found in sediments but are not assimilable by organisms (Rice 1982). This may be particularly true for these sediments because other sources of nitrogen are probably minor. Bacterial numbers and production are very high in these deposits (Alongi et al. 1989, Alongi 1992), but microalgal and protozoan densities are low (Alongi $1990 \mathrm{~b}, \mathrm{c})$. Benthic net primary production is usually undetectable at these stations and rates are low when detected, ranging from 12 to $77 \mathrm{mg} \mathrm{C} \mathrm{m}^{-2} \mathrm{~d}^{-1}$ (Alongi 1990b). Plankton production is moderately high, averaging $563 \mathrm{mg} \mathrm{C} \mathrm{m}^{-2} \mathrm{~d}^{-1}$, but most of the production originates from the nano- and pico-size fractions (Furnas \& Mitchell 1988) which is more likely to be recycled in the water column than to deposit onto the seafloor. Seagrass beds do occur in this region (e.g. near the Brook Islands), but are small in area and likely to export significant quantities of seagrass detritus only over very short distances. For example, Stn MB1 is located $\sim 1 \mathrm{~km}$ from a fringing seagrass bed, which may account for the high infaunal densities at this site, but the quantity of seagrass detritus deposited, although of higher nutritional quality than the mangrove litter (see $\mathrm{C}: \mathrm{N}$ ratios of detritus, Table 2), is small. Seagrass debris or detritus derived from other plants were not found at any of the other stations.

It is possible that higher quality food is deposited in this area as a result of river runoff during the wet season or from phytoplankton blooms resulting from cyclones (Furnas 1989). However, such inputs are episodic and difficult to monitor. Export from the GBR is also possible, but unlikely, considering water mass motion in the lagoon (Wolanski \& Pickard 1985) and the high rates of detrital deposition and utilization within lagoons of individual reefs of the GBR (Hansen et al. 1992). It is therefore likely that these inshore benthic communities are food- (mainly $\mathrm{N}$-) limited, deriving most of their nutrition from the bacteria, litter per se and low standing amounts of microalgae.

The other major factor likely to influence the infaunal communities in this region is physical disturbance. All of these stations are above the shoaling depth for wind waves and tidal scouring. Evidence for 
infrequent physical disturbances may be found in the $\mathrm{X}$-radiographs, particularly from Stns MB3 and MB5. The sedimentary fabric at these sites reveals crossbedding and shell-gravel layers, features that are likely produced by erosional episodes (Rhoads \& Boyer 1982). Summer cyclones, storms and wet-season floods are capable of scouring the seabed in this area (Gagan et al. 1988, 1990). For instance, Cyclone Winifred crossed the central GBR shelf in 1986, producing mud drapes and erosional facies out to $30 \mathrm{~km}$ offshore to a depth of $43 \mathrm{~m}$.

More frequent disturbances may be produced by tidal scouring. With the coincidence of spring tides (up to $3.4 \mathrm{~m}$ ) and low sea-level (sea-level may vary by up to $35 \mathrm{~cm}$; Wolanski \& Gardiner 1981), scouring and resuspension of the seabed is likely to occur, particularly at the shallowest, least protected sites (e.g. Strns MB3, MB4 and MB5). The frequency of such events, especially the oscillations in sea-level, is not entirely determined by astronomical tides and is likely to occur several times a year (Wolanski pers. comm.), perhaps frequent enough to maintain pioneering seres and to retard the establishment of large, equilibrium assemblages (Probert 1984).

The interpretation of the $\mathrm{X}$-radiographs is in good agreement with the $\delta^{13} \mathrm{C}$ and ${ }^{210} \mathrm{~Pb}$ studies of Torgersen \& Chivas (1985) in the same area. They calculated sedimentation rates ranging from 0.2 to $1.0 \mathrm{~cm} \mathrm{yr}^{-1}$, rates that would not necessarily produce clear laminated deposits (which were not observed in the Xradiographs). More importantly, based on the $\delta^{13} \mathrm{C}$ values, most carbon in these sediments is derived from mangrove debris, which also indicates low inputs from other sources. They also calculated mixed-layer thickness, an indication of sediment remixing, and found that the shallowest sites are mixed to a depth of 5 to $30 \mathrm{~cm}$, supporting the idea that these sediments are periodically disturbed. Mixing must occur mainly via physical scouring, resuspension and re-deposition, as there is little bioturbation below the top 5 to $6 \mathrm{~cm}$ at most of these stations (Figs. 2 to 5 ).

In conclusion, it appears that low food availability (poor nutritional value of mangrove litter), periodic disturbances by climatic events and tidal scouring, and, to a much lesser extent, predation by epibenthos and demersal fishes are the major factors regulating the distribution, abundance and structure of benthic infaunal assemblages in this shallow coastal region. These factors perpetuate infaunal assemblages (and their temporal-spatial heterogeneity) that are characteristic of oligotrophic and/or high disturbance regimes (sensu Rhoads \& Boyer 1982) found on other shallow, tropical and subtropical continental shelves (Aller \& Aller 1986, Warwick \& Ruswahyuni 1987, De Wilde et al. 1989). As found in other warm-water regions (e.g.
Rodelli et al. 1984, Fleming et al. 1990), mangroves in the central GBR lagoon exert a significant, but localized, effect on coastal food chains.

Acknowledgements. We thank Otto Dalhaus for sieving all of the infaunal cores and Frank Tirendi for help with the boxcoring. The masters and crew of the RV 'The Harry Messel' are thanked for their assistance. Gary Kershaw of Townsville General Hospital took the X-rays and Karen Handley developed the positive prints. Donna Eddleston and Kathleen Vincent typed the manuscript and A. Sasekumar of the University of Malaya provided constructive comments. This study was partially supported by ARC Grant 86/0708. Contribution No. 649 from the Australian Institute of Marine Science.

\section{LITERATURE CITED}

Aller, J. Y., Aller, R. C. (1986). General characteristics of benthic faunas on the Amazon inner continental shelf with comparison to the shelf off the Changjiang River, East China Sea. Contin. Shelf Res. 6: 291-310

Alongi, D. M. (1987). The influence of mangrove-derived tannins on intertidal meiobenthos in tropical estuaries. Oecologia 71:537-540

Alongi, D. M. (1989). Benthic processes across mixed terrigenous-carbonate sedimentary facies on the central Great Barrier Reef continental shelf. Contin. Shelf Res. 9 $629-663$

Alongi, D. M. (1990a). The ecology of tropical soft-bottom benthic ecosystems. Oceanogr mar Biol. Ann. Rev. 28: $318-496$

Alongi, D. M. (1990b). Effect of mangrove detrital outwelling on nutrient regeneration and oxygen fluxes in coastal sediments of the Central Great Barrier Reef Lagoon. Estuar. coast. Shelf Sci. 31:581-598

Alongi, D. M. (1990c). Abundances of benthic microfauna in relation to outwelling of mangrove detritus in a tropical coastal region. Mar. Ecol. Prog. Ser. 63: 53-63

Alongi, D. M. (1992). Vertical profiles of bacterial abundance, productivity and growth rates in coastal sediments of the Central Great Barrier Reef Lagoon. Mar. Biol. (in press)

Alongi, D. M., Boto, K. G., Tirendi, F. (1989). Effect of exported mangrove litter on bacterial productivity and dissolved organic carbon fluxes in adjacent tropical nearshore sediments. Mar. Ecol. Prog. Ser 56: 129-140

Alongi, D. M., Tirendi, F., Christoffersen, P. (1992). Sedimentary profiles and sediment-water solute exchange of iron and manganese in reef- and river-dominated shelf regions of the Coral Sea. Contin. Shelf Res. 12: (in press)

Belperio, A. P. (1983). Terrigenous sedimentation in the central Great Barrier Reef lagoon: a model from the Burdekin region. BMR J. Aust. Geol. Geophys. 8: 170-190

Boto, K. G., Bunt, J. S. (1981). Tidal export of particulate organic matter from a northern Australian mangrove system. Estuar. coast. Shelf Sci. 13: 247-255

Boto, K. G., Wellington, J. T (1988). Seasonal variations in concentrations and fluxes of dissolved organic and inorganic materials in a tropical, tidally-dominated, mangrove waterway. Mar. Ecol. Prog. Ser. 50: 151-160

Bray, J. R., Curtis, J. T (1957). An ordination of upland forest communities of southern Wisconsin. Ecol. Monogr. 27: $325-349$

Clifford, H. T., Stephenson, W. (1975). An introduction to numerical classification. Academic Press, New York 
Collinson, J. D., Thompson, D. B. (1989). Sedimentary structures. Unwin Hyman, London

Daniel, P. A, Robertson, A. I. (1990). Epibenthos of mangrove waterways and open embayments: community structure and the relationship between exported mangrove detritus and epifaunal standing stocks. Estuar. coast. Shelf Sci. 31. 599-619

De Wilde, P. A., Kastoro, W. J., Berghuis, W. W., Aswandy, I., Al Hakim, I., Kok, A. (1989). Structure and energy demand of the benthic soft-bottom communities in the Java Sea and around the islands of Madura and Bali, Indonesia. Neth. J. Sea Res. 23: 449-461

Duggins, D. O., Simenstad, C. A., Estes, J. A. (1989). Magnification of secondary production by kelp detritus in coastal marine ecosystems. Science 245: 170-173

Fleming, M., Lin, G., da Silveira Lobo Sternberg, L. (1990). Influence of mangrove detritus in an estuarine ecosystem. Bull. mar. Sci. 47: 663-669

Flores-Vergudo, F. J., Day, J. W., Briseno-Duenas, R. (1987). Structure, litter fall, decomposition and detritus dynamics of mangroves in a Mexican coastal lagoon with an ephemeral inlet. Mar. Ecol. Prog. Ser. 35: 83-90

Furnas, M. J. (1989). Cyclonic disturbance and a phytoplankton bloom in a tropical shelf ecosystem. In: Okaichi, T. Anderson, D. M., Nemoto, T. (eds.) Red tides: biology, environmental science and toxicology. Elsevier, Amsterdam, p. 273-276

Furnas, M. J. (1990). In situ growth rates of marine phytoplankton: approaches to measurement, community and species growth rates. J. Plankton Res. 12: 1117-1151

Furnas, M. J., Mitchell, A. W. (1988). Shelf-scale estimates of phytoplankton primary production in the Great Barrier Reef. In: Choat, J. H., et al. (eds.) Proceedings of the Sixth International Coral Reef Symposium, Vol. 2. Sixth International Coral Reef Symposium Executive Committee, Townsville, p. 557-562

Gagan, M. K., Chivas, A. R., Herczeg, A. L. (1990). Shelf-wide erosion, deposition and suspended sediment transport during Cyclone Winifred, Central Great Barrier Reef, Australia. J. sedim. Petrol. 60: 456-476

Gagan, M. K., Johnson, D. P., Carter, R. M. (1988). The Cyclone Winifred storm bed, central Great Barrier Reef shelf, Australia. J. sedim. Petrol. 58: 845-856

Giddins, R. L., Lucas, J. S., Neilson, M. J., Richards, G. N. (1986). Feeding ecology of the mangrove crab Neosarmatium smithi (Crustacea: Decapoda: Sesarmidae). Mar. Ecol. Prog. Ser. 33: 147-155

Graf, G., Bengtsson, W., Faubel, A., Meyer-Reil, L. A., Schulz, R. Theide, H., Thiel, H. (1984). The importance of the spring phytoplankton bloom for the entire benthic system of the Kiel Bight. Rapp. P.-v. Réun. Cons. int. Explor. Mer 183: $138-143$

Graf, G., Schulz, R., Peinert, R., Meyer-Reil, L. A. (1983) Benthic responses to sedimentation events during autumn to spring at a shallow water station in the western Kiel Bight. I. Analysis of processes on a community level. Mar. Biol. 77: 235-246

Hansen, J A., Klumpp, D. W., Alongi, D. M., Dayton, P. K. Riddle, M. J. (1992). Detrital pathways in a coral reef lagoon. II. Detritus deposition, benthic microbial biomass and production. Mar. Biol. (in press)

Hanson, R. B., Tenore, K. R., Bishop, S., Chamberlain, C., Pamatmat, M. M., Tietjen, J H. (1981). Benthic enrichment in the Georgia Bight related to Gulf Stream intrusions and estuarine outwelling. J. mar. Res. 39: $417-441$

Harkantra, S. N., Parulekar, A. H. (1987). Benthos off Cochin, southwest coast of India. Indian J. mar. Sci. 16: 57-59

Hill, M. O., Gauch, H. G. (1980). Detrended correspondence analysis: an improved ordination technique. Vegetatio 43 : $377-389$

Hopkinson, C. S. Jr (1985). Shallow-water benthic and pelagic metabolism: evidence of heterotrophy in the nearshore Georgia Bight. Mar. Biol. 87: 19-32

Lambert, J. M., Williams, W. T. (1962). Multivariate methods in plant ecology. IV. Nodal analysis. J. Ecol. 50: 775-802

Legendre, L., Legendre, P. (1983). Numerical ecology. Elsevier, Amsterdam

Longhurst, A. R., Pauly, D. (1987). Ecology of tropical oceans. Academic Press, New York

Margalef, R. (1958). Information theory in ecology. Gen. Syst. 3: $36-71$

McLusky, D. S., Mclntyre, A. D. (1988). Characteristics of the benthic fauna. In: Postma, H., Zijlstra, J. J. (eds.) Ecosystems of the world, Vol. 27. Continental shelves. Elsevier, Amsterdam, p. 131-154

Pielou, E. C. (1975). Ecological diversity, John Wiley and Sons, New York

Poovachiranon, S., Boto, K. G., Duke, N. C. (1986). Food preference studies and ingestion rate measurements of the mangrove amphipod Parhyale hawaiensis (Dana). J. exp. mar. Biol. Ecol. 98: 129-140

Probert, P. K. (1984). Disturbance, sediment stability and trophic structure of soft-bottom communities. J. mar. Res. 42: 893-921

Rhoads, D. C., Boyer, L. F. (1982). The effects of marine benthos on physical properties of sediments: a successional perspective: In: McCall, P. L., Tevesz, M. J. S. (eds.) Animal-sediment relations, Vol. 2. Plenum Press, New York, p. 3-52

Rice, D. L. (1982). The detritus nitrogen problem: new observations and perspectives from organic geochemistry. Mar. Ecol. Prog. Ser. 9: 153-162

Rice, D. L., Tenore, K. R. (1981). Dynamics of carbon and nitrogen during the decomposition of detritus derived from estuarine macrophytes. Estuar. coast. Shelf Sci. 13: $681-690$

Robertson, A. I., Alongi, D. M., Daniel, P. A., Boto, K. G. (1988). How much mangrove detritus enters the Great Barrier Reef lagoon? In: Choat, J. H., et al. (eds.) Proceedings of the Sixth International Coral Reef Symposium, Vol. 2. Sixth International Coral Reef Symposium Executive Committee, Townsville, p. 601-606

Rodelli, M. R., Gearing, J. N., Gearing, P. J., Marshall, N. Sasekumar, A. (1984). Stable isotope ratio as a tracer of mangrove carbon in Malaysian ecosystems. Oecologia 61: $326-333$

Rowe, G. T (1981). Benthic processes of coastal upwelling ecosystems. In: Richards, F. A. (ed.) Coastal upwelling. American Geophysical Union, Washington, D.C., p. 464-471

Schwinghamer, P. (1981). Extraction of living meiofauna from marine sediments by centrifugation in a silica sol-sorbitol mixture. Can. J. Fish. Aquat. Sci. 38: 476-478

Seshappa, G. (1953). Observations on the physical and biological features of an inshore sea bottom along the Malabar coast. Proc. natn. Inst. Sci. India 19: 257-279

Sokal, R. R., Rohlf, F. J. (1981). Biometry. W. H. Freeman and Co., San Francisco

Tenore, K. R. (1983). Organic nitrogen and caloric content of detritus III. Effect on growth of a deposit-feeding polychaete, Capitella capitata. Estuar coast. Shelf Sci. 17. $733-742$

Tenore, K. R. (1988). Nitrogen in benthic food chains. In: Blackburn, T H., Sorensen, J. (eds.) Nitrogen cycling in 
coastal marine environments. John Wiley \& Sons, Chichester, p. 191-206

Tenore, K. R., Cammen, L., Findlay, S. E. G., Phillips, N. (1982). Perspectives of research on detritus: do factors controlling the availability of detritus to macroconsumers depend on its source? J. mar. Res. 40:473-490

Tietjen, J. H. (1984). Distribution and species diversity of deep-sea nematodes in the Venezuela Basin. Deep Sea Res. 31: 119-132

Tietjen, J. H. (1991). Ecology of free-living nematodes from the continental shelf of the central Great Barrier Reef province. Estuar coast. Shelf Sci. 32: 421-438

Tietjen, J. H., Alongi, D. M. (1990). Population growth and effects of nematodes on nutrient regeneration and bacteria associated with mangrove detritus from northeastern Queensland (Australia). Mar. Ecol. Prog. Ser. 68: $169-179$

Torgersen, T., Chivas, A. R. (1985). Terrestrial organic carbon in marine sediment: a preliminary balance for a mangrove environment derived from ${ }^{13} \mathrm{C}$. Chem. Geol. 52: $379-390$

Twilley, R. R. (1985). The exchange of organic carbon in basin mangrove forests in a Southwest Florida estuary. Estuar. coast. Shelf Sci. 20: 543-557

Valiella, I., Wilson, J., Buchsbaum, R., Rietsma, C., Bryant, D., Foreman, K., Teal, J. (1984). Importance of chemical

This article was submitted to the editor composition of salt marsh litter on decay rates and feeding by detritivores. Bull mar. Sci. 35: 261-269

Warwick, R. M., Ruswahyuni (1987). Comparative study of the structure of some tropical and temperate marine softbottom macrobenthic communities. Mar. Biol. 95: 641-649

Wieser, W. (1953). Die Beziehung zwischen Mundhöhlengestalt, Ernährungsweise und Vorkommen bei freilebenden marinen Nematoden. Ark. Zool. 4: 439-484

Wolanski, E., Gardiner, R. (1981). Flushing of salt from mangrove swamps. Aust. J. mar. Freshwat. Res. 32: $681-683$

Wolanski, E., Jones, M., Bunt, J. S. (1980). Hydrodynamics of a tidal creek-mangrove swamp system. Aust. J mar. Freshwat. Res. 31: 431-450

Wolanski, E., Mazda, Y., King, B., Gay, S. (1990). Dynamics, flushing and trapping in Hinchinbrook Channel, a giant mangrove swamp, Australia. Estuar. coast. Shelf Sci. 31: $555-579$

Wolanski, E., Pickard, G. L. (1985). Long-term observations of currents on the central Great Barrier Reef continental shelf. Coral Reefs 4:47-57

Zieman, J. C., Macko, S. A., Mills, A. L. (1984). Role of seagrasses and mangroves in estuarine food webs: temporal and spatial changes in stable isotope composition and amino acid content during decomposition. Bull. mar. Sci. 35: $380-392$

Manuscript first received: November 8, 1991

Revised version accepted: March 23, 1992 